\title{
Seasonality of beachwrack at Oakajee in the mid-west region of Western Australia
}

\author{
Fred E. Wells \\ Western Australian Museum Perth, Western Australia 6000, Australia \\ Email: wellsf@museum.wa.gov.au
}

\begin{abstract}
This study examines seasonal fluctuations in beachwrack accumulations near Oakajee, Western Australia $\left(28^{\circ} 34^{\prime} \mathrm{S} ; 114^{\circ} 34^{\prime} \mathrm{E}\right)$. Twelve monthly samples were made of beachwrack concentrations at Drummonds Cove and Coronation Beach from 5 May 1998 until 10 April 1999. Four weekly samples were made from 23 July to 12 August 1998 to measure short-term variations in beachwrack volumes. There was no seasonality in beachwrack accumulations at Drummonds Cove. At Coronation Beach beachwrack concentrations were high in late summer and early winter, but declined sharply from late winter to early spring. There was considerable movement of wrack onto and off the beaches. Beachwrack accumulations migrated along the beach within Drummonds Cove, but there was no evidence of such longshore movement on the open coast. Beachwrack accumulates in bays and other protected areas and at the tip of peninsulas, such as Point Moore. Macroalgae and the seagrass genera Amphibolis and Posidonia dominated the wrack.
\end{abstract}

Keywords: beachwrack, macrophytes, Western Australia, seagrass, seaweeds, macroalgae

\section{INTRODUCTION}

Oceanic waters off Western Australia are nutrient poor, at levels characteristic of the open ocean. Consequently, phytoplankton production is minimal (Rochford, 1980; Pearce 1991; 1997). Instead benthic plants, both seagrass and macroalgae, provide most of the primary production. The plants are torn from the bottom during storms and then moved about by currents and waves. A portion is transported to shore where it accumulates as beachwrack. The beachwrack is reworked by wind and waves, accumulating in some areas and being absent in others. It is mobile, often alternating between the water and the beach. Volumes change considerably over short periods of time (Hansen, 1984).

Beachwrack in the Perth area develops an abundant invertebrate fauna which feeds on it. The invertebrates are dominated by amphipods, particularly Allorchestes compressa (Robertson \& Lucas, 1983; McLachlan, 1985; Fong, 1999). Nearshore the beachwrack and associated invertebrates provide shelter and food for a variety of fish species (Lenanton, 1982; Lenanton et al., 1982; Robertson \& Lenanton, 1984), including the commercially important cobbler Cnidoglanis macrocephalus (Lenanton \& Caputi, 1989), and abalone (Wells \& Keesing, 1989). Nutrients are released back into the water column as the beachwrack decomposes (Robertson \& Hansen, 1982). This recycling is important in the low nutrient environment off Western Australia.

The present study extends our knowledge of beachwrack accumulations to Oakajee, just north of Geraldton. The study tested the hypotheses that beachwrack accumulates seasonally, with a maximum due to winter storms, and once on the beach, the beachwrack migrates longshore in response to prevailing wave and wind directions.

\section{THE OAKAJEE MARINE ENVIRONMENT}

The Oakajee region (Figure 1) is an open, exposed coastline subject to the full force of sea conditions, particularly during storms. It is thus a very high energy environment. Virtually the entire shoreline from Geraldton north to the mouth of the Bowes River is composed of intertidal sand. Beachrock platforms occur along the shoreline throughout the Oakajee region but are more common north of the Oakabella River. They range from small platforms of a few square metres to an extensive platform just south of Coronation Beach. The platforms begin at the low tide level and continue into the subtidal region. Large portions may be exposed by winter wave action then recovered by sand the following summer. The platforms at Oakajee have a greatly reduced biota, possibly due to the dynamic wave 


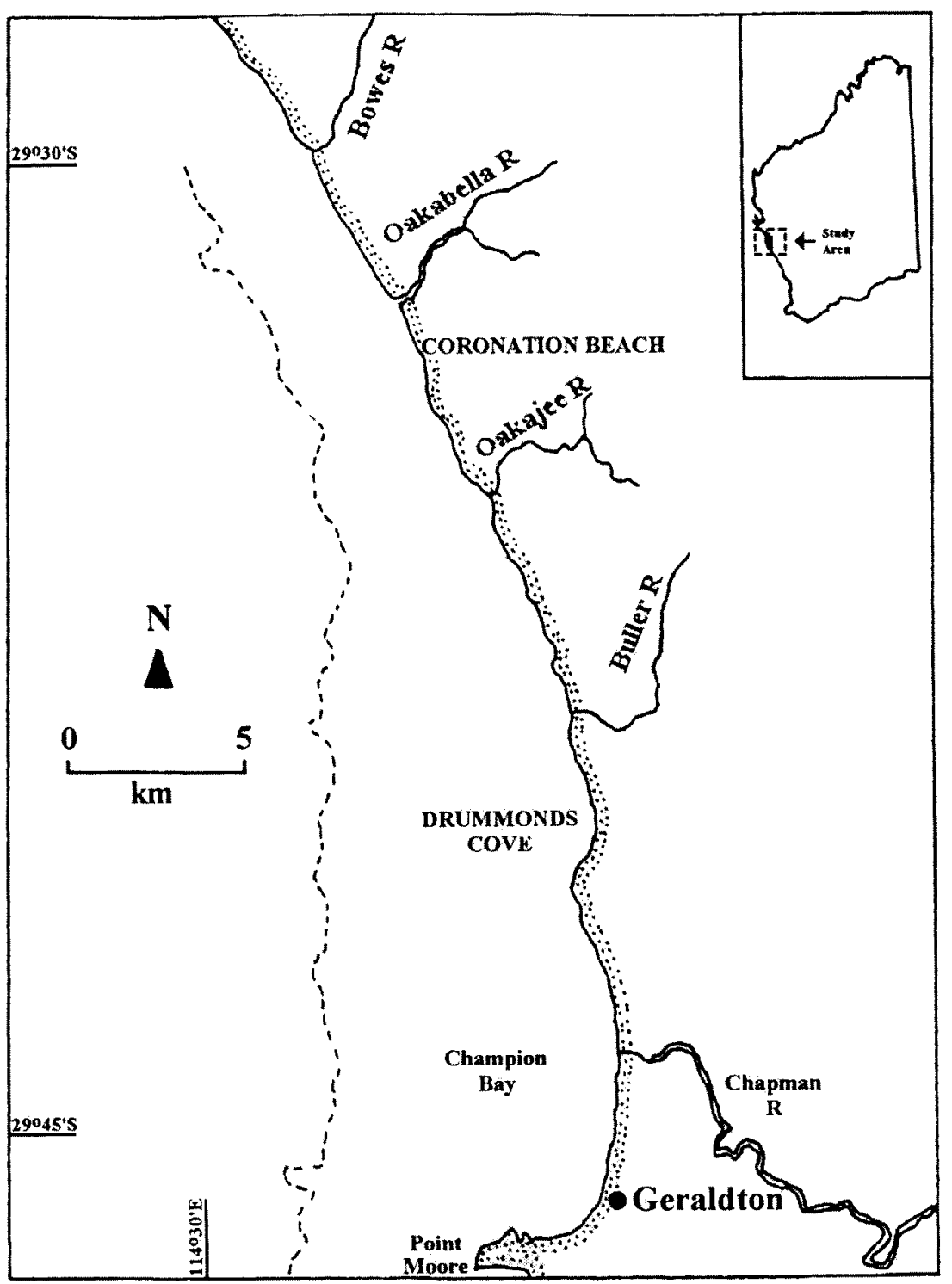

Figure 1 Map of the Oakajee coastline showing localities mentioned in the text.

action at Oakajee that would physically remove much of the macroalgae and fauna. In addition, sand moved about by the waves would provide a considerable scouring force.

In the nearshore environment the substrate is limestone that may or may not be covered with sand. While considerable local variation in depth occurs, there is a steady progression of habitats from the intertidal sand beach out to the $20 \mathrm{~m}$ line. A shallow lagoon up to $5 \mathrm{~m}$ deep occurs near the shore. The lagoon is more distinct south of the Oakajee River. North of the Oakajee, the lagoon is less distinct and has numerous bombies, many of which nearly reach the sea surface. An indistinct limestone reef occurs to the west of the lagoon. The reef runs north to south paraliel to the shore, and is absent only off the mouth of the Oakajee River. In most areas the reef shoals to a depth of $2 \mathrm{~m}$ or less, but in some localities it is less distinct.
Seaward of the reef crest is a low relief platform. While the platform surface is not uniform, it tends to have a gradually increasing depth seaward. Small crevices and depressions occur throughout the surface of the limestone. The platform is channelled with a very small spur and groove formation in some areas, where the undulations may be $30 \mathrm{~cm}$ or less in height. The surfaces of the crest are exposed limestone. The channels are either exposed limestone or are covered by a thin layer of sand. Sand accumulates in the depressions, some of which are large, tens of metres across. In some low energy areas of the bottom the entire limestone platform is covered by a layer of sand several centimetres deep. In deeper waters, where depths are between 15 and $20 \mathrm{~m}$, the platform gives way to a level bottom that is predominantly covered with sand, but there are exposed areas of flat limestone.

The bottom habitats can change considerably over 
a space of a few metres, particularly in the shallow inshore waters and the high relief reef. Over a space of 100 to $200 \mathrm{~m}$ going seaward, the bottom can vary from high relief reef with sand patches in the depressions, to a low relief reef dominated by the seagrass Amphibolis antarctica, to areas codominated by $A$. antarctica and macroalgae, to areas where only macroalgae are present. There may also be sandy bottoms where $A$. antarctica forms a dense seagrass meadow. The ability of $A$. antarctica to live on either sandy or rocky bottoms is well demonstrated at Oakajee.

Shallow vertical columns, which occur near the shore south of the Oakajee River, are one of the most distinctive features of the marine environment in the Oakajee area. The columns, which may have a diameter of 5-10 m or more, emerge vertically from sand at a depth of up to $5 \mathrm{~m}$ to near the lower intertidal level. This is an area of breaking waves during even moderate seas. The upper surfaces of the columns are largely devoid of macroalgae, but may be colonised by small patches of Sargassum which are kept to short lengths by the continuous wave action. The Sargassum is longer on the sides of the columns than on the upper surfaces. On the leeward side of the columns is a mixture of low encrusting species of macroalgae, including Caulerpa. The base of the columns is at a depth of approximately $6 \mathrm{~m}$ and is surrounded by sand mixed with some Amphibolis. There may be small patches of Sargassum inshore. Invertebrate diversity on the tops of the columns is low.

\section{MATERIALS AND METHODS}

Twelve aerial flights were made at approximately monthly intervals over the coastline at Oakajee (28 34'S; $114^{\circ} 34^{\prime}$ E) from 5 May 1998 until 10 April 1999 using a Cessna 172 aircraft. Most flights were made at $140-165 \mathrm{~km} \mathrm{~h}^{-1}$ at an altitude of $100 \mathrm{~m}$ from south of the Port of Geraldton to the mouth of the Bowes River, a distance of approximately $40 \mathrm{~km}$. A video recording was made of the entire shoreline on the flight north. A still camera was used on the flight south to photograph major beachwrack accumulations. Four weekly flights were made from 23 July to 12 August 1998 to measure short-term variations in beachwrack volumes.

The only major accumulations of beachwrack on the first flight were at Drummonds Cove and at Coronation Beach. As vehicle access to the shore was possible, the two beaches were chosen for ground truthing. On most occasions the two sites were the locations with the greatest beachwrack concentrations. Methods used by Hansen (1984) were used to determine beachwrack volumes on the shoreline. Length and width of beachwrack accumulations at Drummonds Cove and at Coronation Beach were measured. Length was stepped off and compared with the number of steps required to cover a known distance. Width and depth were measured at consistent intervals with a tape measure marked to the nearest $1 \mathrm{~cm}$. The intervals were calculated to provide at least 6 measurements at each of the two localities; usually 8-10 measurements were made. Width of beachwrack was measured to the nearest $10 \mathrm{~cm}$ from the seaward to the landward edge of the beachwrack. Depth was normally measured to the nearest $1 \mathrm{~cm}$ at three locations: top of the seaward beachwrack crest, middle of the accumulation, and the landward margin; only two measurements of depth were made in small accumulations where there was little beachwrack present. Total volume of beachwrack on each beach was then calculated.

To measure the composition of beachwrack, four samples were collected each at Drummonds Cove and at Coronation Beach on 12 June 1998 and 16 January 1999, placed in labelled plastic bags and frozen until analysis. Samples were collected from freshly deposited areas of wrack to minimise the proportion of unidentifiable detritus. The samples were washed in freshwater then sorted to five major plant types: macroalgae, the seagrass genera Amphibolis, Posidonia and Halophila, and unidentified plant material. Individual components were placed on aluminium foil and dried for 48 hours in a drying oven at $80^{\circ} \mathrm{C}$. They were then weighed to the nearest $1 \mathrm{mg}$ on a Sartorius electronic balance.

\section{RESULTS}

The greatest accumulations found during the first survey on 5 May 1998 were at Drummonds Cove, where $7559 \mathrm{~m}^{3}$ of beachwrack occurred on the shoreline, and at Coronation Beach, where there was $2477 \mathrm{~m}^{3}$ (Figure 2). Smaller accumulations occurred in other areas. Accumulations at Drummonds Cove were consistently the largest along the shoreline between Drummonds Cove and the Bowes River, some $25 \mathrm{~km}$ of coastline.

\section{Seasonal variation}

The predicted pattern of seasonality was not clearly demonstrated at Drummonds Cove during the study (Figure 2). The accumulation at Drummonds Cove on 7 May 1998 was spread over an estimated $1786 \mathrm{~m}$ of beach. As expected, the beachwrack increased to $8510 \mathrm{~m}^{3}$ on 12 June, but instead of continuing to increase during the winter, wrack volumes declined sharply, reaching a low of $817 \mathrm{~m}^{3}$ on 6 August. Wrack accumulations at Drummonds Cove increased to $3154 \mathrm{~m}^{3}$ one week later on 13 August. They continued to increase until 9 October, when a peak of $7436 \mathrm{~m}^{3}$ was reached. Significant accumulations remained for the remainder of the study, varying from $3196 \mathrm{~m}^{3}$ to $5780 \mathrm{~m}^{3}$ over 


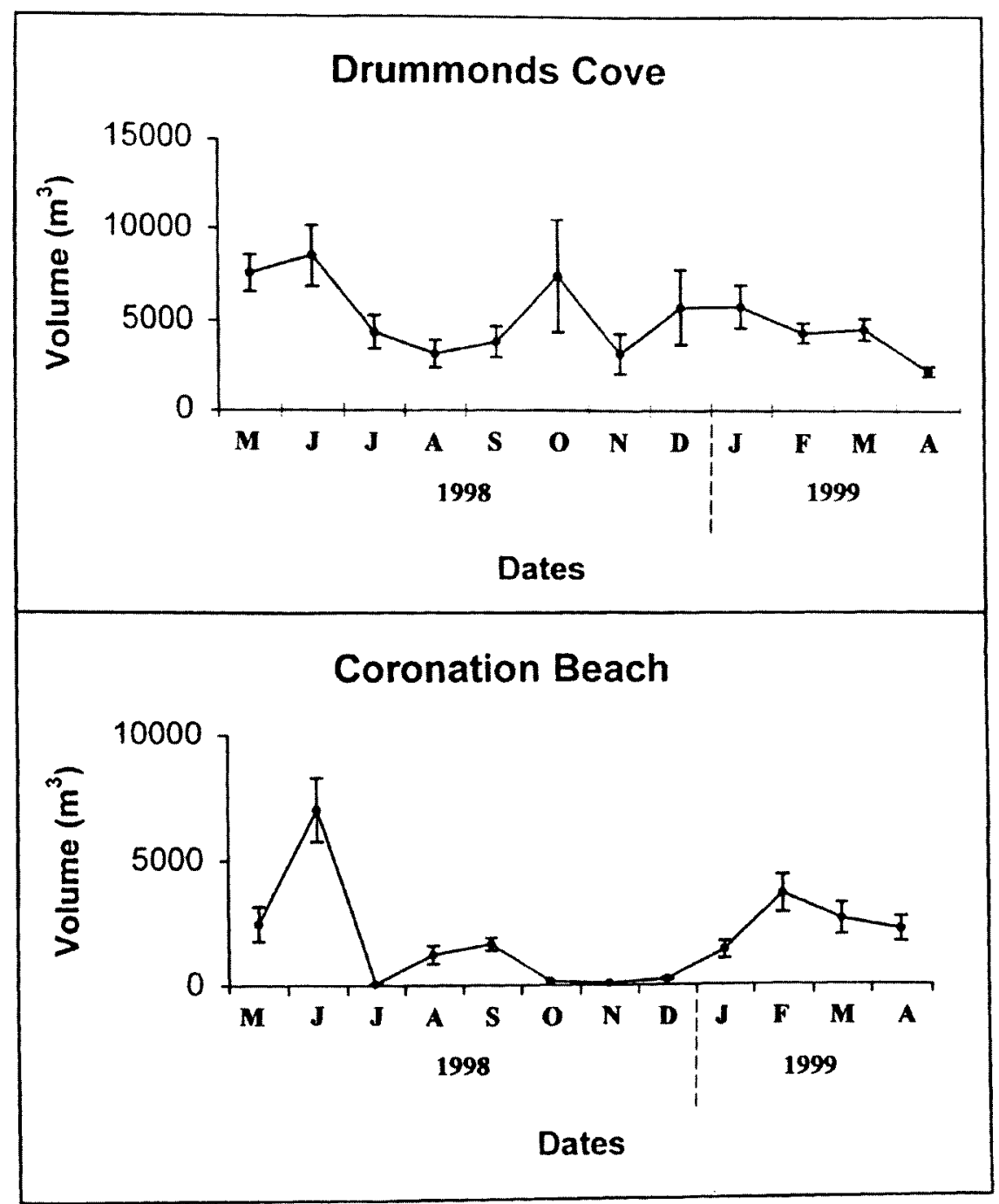

Figure 2 Seasonal patterns of accumulation of beachwrack at Drummonds Cove and Coronation Beach from May 1998 to April 1999. Means and standard errors are shown.

summer, declining to $2221 \mathrm{~m}^{3}$ on the final month of the survey (10 April 1999).

In contrast, the pattern at Coronation Beach was seasonal (Figure 2). Accumulations totalled $2477 \mathrm{~m}^{3}$ on 7 May 1998 and were along $629 \mathrm{~m}$ of beach. The beachwrack increased significantly to $7043 \mathrm{~m}^{3}$ on 12 June. During the period of late winter to early summer beachwrack at Coronation Beach declined to low levels, ranging from $58 \mathrm{~m}^{3}$ on 23 July to 443 $\mathrm{m}^{3}$ on 11 September. Beachwrack volumes increased sharply to $3647 \mathrm{~m}^{3}$ on 20 February (late summer) and remained relatively high for the duration of the study.

\section{Short-term variation}

Considerable short-term variation was found during the four week intensive survey at Drummonds Cove (Figure 3). Concentrations at Drummonds totalled $4372 \mathrm{~m}^{3}$ on 23 July. Two weeks later they had dropped to $817 \mathrm{~m}^{3}$. Beachwrack increased during the next week to $3154 \mathrm{~m}^{3}$.
In contrast to Drummonds, the four week intensive survey at Coronation Beach showed little variation in beachwrack concentrations (Figure 3). During the first three weeks (23 July, 30 July and 6 August) there was essentially no beachwrack present. An increase to $1221 \mathrm{~m}^{3}$ occurred by 13 August.

\section{Longshore movement}

There was no clear evidence of longshore movement of beachwrack along the Oakajee coastline, but the rapidly changing volumes, particularly during the short term study at Drummonds Cove, showed that there is considerably flux in wrack between the shore and the offshore waters.

At the beginning of the study, beachwrack occupied much of the bay at Drummonds Cove. It moved several hundred metres to the north during the winter and early spring, but remained in Drummonds Cove. In spring fresh build-ups 


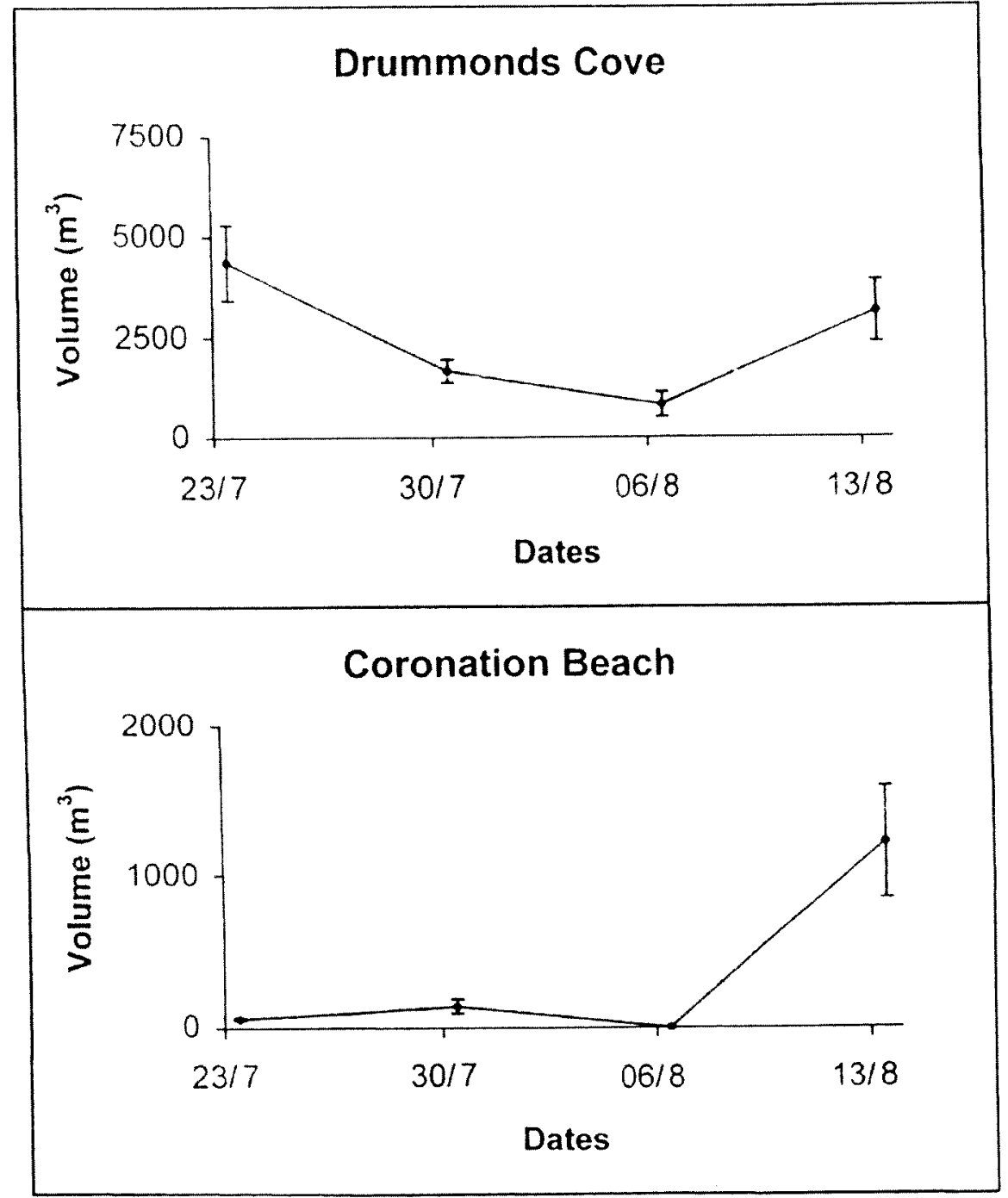

Figure 3 Short-term variations in accumulation of beachwrack at Drummonds Cove and Coronation Beach in July and August 1998. Means and standard errors are shown.

Table 1 Composition of beachwrack at two locations along the Oakajee coastline in winter 1998 and summer 1999.

\begin{tabular}{|c|c|c|c|c|c|c|}
\hline & Algae & Amphibolis & $\begin{array}{l}\text { Seagrasses } \\
\text { Posidonia }\end{array}$ & Halophila & Detritus & Total \\
\hline \multicolumn{7}{|c|}{$\begin{array}{c}\text { DRUMMONDS COVE } \\
\text { Winter } 1998\end{array}$} \\
\hline Mean $( \pm S E)(\mathrm{gm})$ & $10.5 \pm 1.5$ & $3.9 \pm 0.3$ & $2.7 \pm 0.8$ & $0 \pm 0$ & $3.8 \pm 1.3$ & $20.9 \pm 3.1$ \\
\hline Percentage & 50.2 & 18.8 & 12.9 & 0.0 & 18.1 & 100.0 \\
\hline \multicolumn{7}{|c|}{ Summer 1999} \\
\hline Mean $( \pm S E)(\mathrm{gm})$ & $11.5 \pm 1.7$ & $8.8 \pm 1.4$ & $0.7 \pm 0.2$ & $0 \pm 0$ & $2.3 \pm 0.7$ & $23.3 \pm 0.9$ \\
\hline Percentage & 49.4 & 37.8 & 3.2 & 0.0 & 9.7 & 100.1 \\
\hline \multicolumn{7}{|c|}{$\begin{array}{c}\text { CORONATION BEACH } \\
\text { Winter } 1998\end{array}$} \\
\hline Mean $( \pm S E)(\mathrm{gm})$ & $12.5 \pm 1.2$ & $16.4 \pm 1.1$ & $1.0 \pm 0.3$ & $0 \pm 0$ & $3.4 \pm 0.4$ & $33.3 \pm 2.2$ \\
\hline Percentage & 37.6 & 49.1 & 3.0 & 0.0 & 10.2 & 99.9 \\
\hline \multicolumn{7}{|c|}{ Summer 1999} \\
\hline Mean $( \pm \mathrm{SE})(\mathrm{gm})$ & $20.4 \pm 3.1$ & $17.3 \pm 3.9$ & $3.6 \pm 0.4$ & $0 \pm 0$ & $3.2 \pm 1.4$ & $44.5 \pm 5.9$ \\
\hline Percentage & 45.9 & 38.8 & 8.1 & 0.0 & 7.2 & 100.0 \\
\hline
\end{tabular}


developed along the southern shoreline of Drummonds Cove and remained there for the duration of the study.

At Coronation Beach two accumulations during May 1998 were on the northern and southern ends of the beach. The southern accumulation disappeared by June. The beachwrack to the north increased in June, but then decreased over time. Beachwrack accumulations increased over summer, and by February the entire margin of the bay was fringed with beachwrack.

There was no longshore movement of other beachwrack accumulations or drift macroalgae viewed during the aerial surveys. In particular, a major accumulation of beachwrack south of the mouth of the Chapman River remained at consistently high levels and maintained a constant position. The aerial surveys found beachwrack accumulations on the southern shoreline of the port of Geraldton, but they were not substantial. The aerial examination and several shoreline searches demonstrated that beachwrack also accumulates along the Geraldton beaches just north of the port. The mouth of the Chapman River consistently had the largest accumulations south of Drummonds Cove. These were measured on 5 December 1998, and had an estimated volume of $4907 \mathrm{~m}^{3}$, somewhat smaller than the accumulation of $5780 \mathrm{~m}^{3}$ at Drummonds Cove on the same day. The western tip of the port of Geraldton has a small bay near the southern tip of the peninsula; this area regularly trapped beachwrack.

\section{DISCUSSION}

The pattern of beachwrack accumulations varied between Drummonds Cove and Coronation Beach. There was no seasonality at Drummonds Cove. In contrast, at Coronation Beach beachwrack concentrations were high in late summer and early winter, but declined sharply from late winter to early spring. Experience in other areas of Western Australia has been similarly mixed. Some areas have winter maxima, but others do not. Beachwrack accumulates seasonally during winter at the southern groyne at Port Geographe in Busselton ( $P$. Collins, pers. comm). Kirkman (1984) reported considerable interannual variation in beachwrack quantities in the Marmion lagoon. Different patterns of seasonality occurred during the years studied. Hansen (1984) examined beachwrack along $46 \mathrm{~km}$ of coast from Triggs to Two Rocks, and found similar variability between sites, seasonally and between years. A series of photographs published by Kirkman \& Kendrick (1997) also demonstrates high short-term variability in beachwrack concentrations. The results of all these studies demonstrate that the timing and magnitude of beachwrack accumulations are highly dependent on local conditions and may vary considerably across a range of time scales (days/months/years) at a single location.

It was thought that once on the beach at Oakajee, the beachwrack would migrate north or south along the shore in response to prevailing wave and wind directions. This did occur within Drummonds Cove, but there was no evidence of such longshore movement on the open coast. Instead, the beachwrack accumulates in bays and other protected areas and at the tip of peninsulas, such as Point Moore. Working on the northern Perth beaches, Hansen (1984) obtained mixed results. Some sites had predictable, large quantities of beachwrack, which remained in the same area. Concentrations at other sites were less predictable and the beachwrack moved along the shoreline. Clear patterns of longshore movement occur in Geographe Bay. Beachwrack reaches the shore from Dunsborough to Busselton and moves northward along the shoreline until it reaches Port Geographe (P. Collins, pers. comm.). A major accumulation of $70-80,000 \mathrm{~m}^{3}$ occurred along the southern side of the development at the end of winter in 1998; it was prevented from moving northwards by the groyne.

Composition of beachwrack is variable, depending on the material available in the offshore environment. Beachwrack at Oakajee is a combination of macroalgae and the seagrass Amphibolis. Hansen (1984) found beachwrack in the northern portion of the Perth area to be composed of a variety of constituents, including the kelp Ecklonia radiata, seagrasses and numerous small macroalgae. In Hansen's (1984) study of the Perth area, E. radiata was dominant over a full year, followed by other macroalgae, then seagrass. Sargassum was seasonally important during summer.

Only a small proportion of detached macrophytes ends up on the beach. For example, Kirkman \& Kendrick (1997) released 5000 tagged Ecklonia radiata in the Marmion Lagoon in winter 1985. The tagged plants took 15 to 23 days to reach shore, but only $53(1 \%)$ were recovered on beaches. In her detailed study of beachwrack in the Perth metropolitan area, Hansen (1984) found considerable variation in the amount of beachwrack, from 1.3 to $45.3 \mathrm{~kg}$ dry weight per metre of coastline. On average there was 74 to 80 tonnes of carbon per kilometre of coastline, equivalent to about $18 \%$ of the nearshore macrophyte production. These figures emphasise that the material in the beachwrack is only a fraction of total macrophyte production in nearshore waters.

\section{ACKNOWLEDGEMENTS}

Caroline Bodenham of the Central West College 
of Technical and Further Education provided considerable enthusiastic assistance in the field at Geraldton. In addition, Greg Burrows, Barbara Larkin, Priscilla Rodd, and David Wells each assisted on one trip. Contact with TAFE was through Steven Webster. Chris Shine and his pilots and staff at Shine Aviation Services provided skilful services during the low level overflights of the beaches at Oakajee. In addition the following people are thanked for their assistance in providing information on the project: Peter Collins and Ian LeProvost, LeProvost Dames \& Moore; Dr Gary Kendrick, Department of Botany, University of Western Australia; and Kim Nardi and Randall Owens of Fisheries Western Australia, Geraldton. Dr Gary Kendrick and Dr Anne Brearley kindly commented on the manuscript, which substantially improved the paper.

This information was originally generated as part of a study of the potential effects of the construction of a new deepwater port at Oakajee. It was done under a contract between the Western Australian Department of Resources Development and LeProvost Dames \& Moore (now part of URS Australia). I am grateful to DRD for permission to publish the information and to Peter Goodall and David Meehan at DRD for their considerable help and encouragement during the project.

\section{REFERENCES}

Fong, T.C.W. (1999). The relationship between seagrass canopy, detritus accumulation and amphipod abundance in Thomson Bay, Rottnest Island. Pp. 247253. In Walker, D.I. and Wells, F.E. (Editors.). The seagrass flora and fauna of Rottnest Island, Western Australia. Western Australian Museum, Perth.

Hansen, J.A. (1984). Accumulations of macrophyte beachwrack along sandy beaches in Western Australia: biomass, decomposition rates and significance in supporting nearshore production. Unpublished PhD thesis, University of Western Australia. 93 pages.

Kirkman, H. (1984). Standing stock and production of Ecklonia radiata (C.Ag.) J. Agardh. Journal of Experimental Marine Biology and Ecology 76: 119-130.

Kirkman, H. and Kendrick, G.A. (1997). Ecological significance and commercial harvesting of drifting and beach-cast macro-algae and seagrasses in Australia: a review. Journal of Applied Phycology 9 : 311-326.
Lenanton, R.C.J. (1982). Alternativ non-estuarine nursery habitats for some commercially and recreationally important fish species of south Western Australia. Australian Journal of Marine and Freshwater Research 33: 881-900.

Lenanton, R.C.J and Caputi, N. (1989). The roles of food supply and shelter in the relationship between fishes, in particular Cnidoglanis macrocephalus (Valenciennes), and detached macrophytes in the surf zone of sandy beaches. Journal of Experimental Marine Biology and Ecology 128: 165-176.

Lenanton, R.C.J., Robertson, A.I. and Hansen, J.A. (1982). Nearshore accumulations of detached macrophytes as nursery areas for fish. Marine Ecology Progress Series 9 : $51-57$

McLachlan, A. (1985). The biomass of macro- and interstitial fauna on clean and beachwrack-covered beaches in Western Australia. Estuarine Coastal and Shelf Science 21: 597-599.

Pearce, A.F. (1991). Eastern boundary currents of the southern hemisphere. Pp. 35-45. In Pearce, A.F. and Walker, D.I. (Editors.) The Leeuwin Current: An Influence on the Coastal Climate and Marine Life of Western Australia. Journal of the Royal Society of Western Australia 74.

Pearce, A.F. (1997). The Leeuwin Current and the Houtman Abrolhos Islands. Pp. 11-46. In Wells, F.E. (Editor). The Marine Flora and Fauna of the Houtman Abrolhos Islands, Western Australia. Western Australian Museum, Perth. Volume 1.

Robertson, A.I. and Hansen, J.A. (1982). Decomposing seaweed: a nuisance or a vital link in coastal food chains. CSIRO Marine Laboratories Research Report 1979-1981: 75-83.

Robertson, A.I. and Lenanton, R.C.J. (1984). Fish community structure and food chain dynamics in the surf-zone of sandy beaches: role of detached macrophyte detritus. Journal of Experimental Marine Biology and Ecology 84: 265-283.

Robertson, A.I. and Lucas, J.S. (1983). Food choice, feeding rates and the turnover of macrophyte biomass by a surf-zone inhabiting amphipod. Jourmal of Experimental Marine Biology and Ecology 72: 99-124.

Rochford, D.J. (1980). Nutrient status of the oceans around Australia. CSIRO Division of Fisheries and Oceanography Annual Report 1977-79: 9-20.

Wells, F.E. and Keesing, J.K. (1989). Reproduction and feeding of the abalone Haliotis roei Gray. Australian Journal of Marine and Freshwater Research 40: 187-197.

Manuscript received 20 February 2002; accepted 6 June 2002 